\title{
Water contact activities and schistosomiasis infection in Menoufia, Nile Delta, Egypt
}

Amal E.M. Khair'

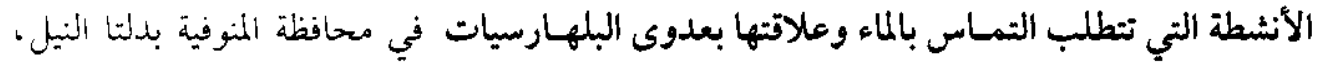

$$
\begin{aligned}
& \text { آمال المسيد معمد خيري }
\end{aligned}
$$

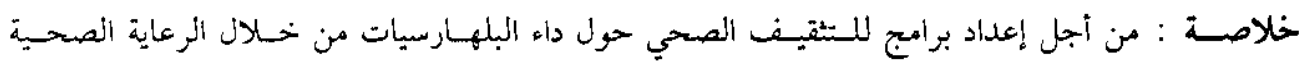

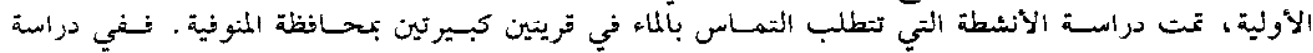

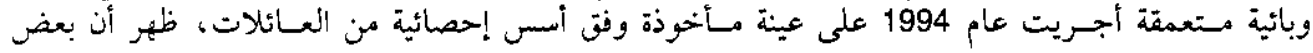

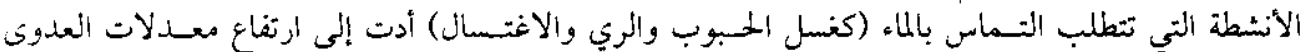

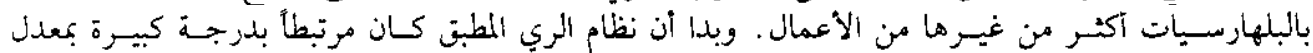

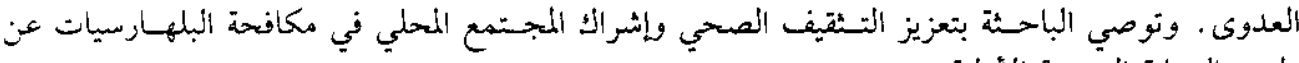

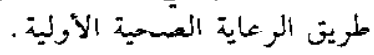

ABSTRACT With the aim of developing schistosomiasis health education programmes through primary health care, water contact activities were studied in two large villages in Menoufia Governorate. In 1994, an in-depth epidemiological study performed on a calculated sample of households revealed that certain water contact activities (grain washing, irrigation, ablution) resulted in higher schistosomiasis infection rates than others. The irrigation system used appeared to be significantly related to the infection rate. Health education and community participation in schistosomiasis control via primary health care are recommended.

Les activités impliquant un contact avec l'eau et la schistosomiase à Menoufia dans le Delta du Nil (Egypte)

RESUME Dans le but de mettre en place des programmes d'éducation sanitaire concernant la schistosomiase dans le cadre des soins de santé primaires, les activités impliquant un contact avec l'eau ont fait l'objet d'une étude dans deux gros villages du Gouvernorat de Menoufia. En 1994, une étude épidémiologique approfondie qui a été réalisée sur un échantillon calculé de ménages a révélé que certaines activités impliquant un contact avec l'eau (lavage du grain, irrigation, ablutions) entraînaient des taux supérieurs d'infection par le schistosome par rapport a d'autres activités. Le taux d'infection semble être lié de manière significative au système d'irrigation utilisé. L'éducation sanitaire et la participation communautaire pour la lutte contre la schistosomiase par le biais des soins de santé primaires sont recommandées.

'Professor, Primary Health Care, High Institute of Public Health, Alexandria University, Alexandria, Egypt. Received: 22/09/96; accepted: 03/07/97 


\section{Introduction}

In Egypt, epidemiological water contact studies have identified a wide range of human behavioural activities associated with exposure to schistosomiasis infection [13]. In past studies, different canal water contact activities have been found to vary in weight as risk factors. Exposed body parts in each activity appear to play a role in determining the risk of schistosomiasis infection. Yet to change behaviour is a long and involved process, particularly when such behaviour has a sociocultural or occupational nature and there are logical reasons for it.

An in-depth study of water contact activities in various parts of Egypt found many factors behind the persistent use of canals for domestic purposes, even when a safe water supply is available. Furthermore, the lack of control programmes with regard to re-exposure and reinfection has allowed the schistosomiasis problem to continue [4].

On the other hand, simple modifications in water contact patterns could minimize infection risk and primary health care could play an effective part in this respect. Ecological conditions which are optimal for the existence of the snail vector and the release of cercaria could be avoided in the choice of water contact sites. Moreover, health education programmes could be more intensively directed towards high infection risk activities as found by water contact and schistosomiasis epidemiological studies.

This study, therefore, aimed at studying schistosomiasis infection in two different village settings in Menoufia governorate in relation to water contact activities and sites in order to enhance the effectiveness of primary health care in schistosomiasis control.

\section{Methods}

\section{Study sample and setting}

A purposive sample of two large villages was chosen in Menoufia governorate, representing its various environmental situations. El-Garda village, with a population of 7679 , has a sewage disposal system which covers about half the village households. Salamoniya, with a population of 8181 (1991 census, which was a recensus performed by the project), has no sewage disposal system. In both villages, most households have a piped water supply, but wastewater disposal is not provided in Salamoniya and in parts of El-Garda. Therefore, many households, particularly those in the vicinity of water courses, have installed disposal pipes which empty into the canals that pass through the villages. Moreover, much of the sewage collected by the disposal plant is often ultimately dumped into the canals.

The two villages are densely settled and, in spite of the availability of piped water, canal water is still used for many domestic purposes, and water contact for irrigation purposes occurs for many hours during the day.

\section{Pilot study}

This was performed on $5 \%$ of the recensused households of the two villages in 1992. Urine and stool examinations were carried out using nucleopore filtration and the Kato thick smear preparation technique, respectively. Since it was preferred not to depend on census data that was already available in health and other facilities in the region, the studied villages were censused by the project team before proceeding with research (1991). Prevalence rates of Schistosoma haematobium in both villages were found to be $<2 \%$, and therefore 
the in-depth study was restricted to $S$. mansoni.

\section{In-depth epidemiological study}

This was conducted from 1992 to 1994 on a calculated sample of houscholds from both villages [4] totalling 1379 individuals (949 in El-Garda and 430 in Salamoniya in 1994) for the purpose of determining the schistosomiasis prevalence and incidence rates.

A water contact questionnaire was given to the chosen sample which investigated canal contact behaviour for domestic and occupational purposes. Questionnaires with non-specific answers about purpose or site of water contact were rejected from the water contact questionnaire sample and the final sample was 402 individuals (164 in Salamoniya and 238 in El-Garda).

Anthropological and laboratory findings were analysed to demonstrate existing relationships, which were interpreted using other collected relevant ecological data in the two villages.

\section{Results}

As a whole, schistosomiasis infection rates were much higher in Salamoniya village as related to water contact with its canals. Prevalence rates of $S$. mansoni during the study were $27.9 \%$ in Salamoniya and $8.1 \%$ in El-Garda.

Table 1 shows that in Salamoniya the occupational exposure of wheat washing was the activity related to the highest schistusomiasis infection rate $(96.2 \%)$, followed by ablution $(79.0 \%)$. Wheat washing is a procedure that takes place to prepare wheat for milling. Thus, wheat is soaked in canal water in large containers and then spread out to dry. It usually takes place either in water courses passing through fields or in front of wheat mills. It involves intermittent water contact for a considerable length of time. Ablution is the ritual washing prior to prayers and may be repeated several times a day. Many villagers perform this activity in the canal. In Ll-Garda, irrigation was the activity related to the highest rate of $S$. mansoni infection (37.9\%), closely followed by ablution (35.3\%).

Table 2 shows the habitual water contact canals and their relationship with $S$. mansoni infection in each village. In Salamoniya, the rate of $S$. mansoni infection was higher with El-Salmoniya canal contact $(67.4 \%)$ than with Dia El-Kom canal contact $(64.8 \%)$. However, the difference was not statistically significant. In El-Garda vfllage, a significant difference existed between the infection rate in users of Kafr Tambidy canal $(49.1 \%)$ and that in users of El-Garda canal $(28.5 \%)(P<0.01)$.

\section{Discussion}

In previous water contact studies in the Nile Delta, the risk of schistosomiasis infection was found to be related to the surface area of the body exposed to canal water. Moreover, the length of exposure time proved to be positively related to schistosomiasis infection. Together, these factors seem to have a role in determining the infection risk connected with different water contact activities. Kloos and Lemma [5] actually constructed an exposure index based on the product of frequency, duration and intensity of water contact (proportion of body surface exposed) which is used to predict infection.

The findings of the present study show that three Inain activities were related to the highest schistosomiasis infection rateswheat washing, irrigation and ablution. The flrst two activities are occupational work 


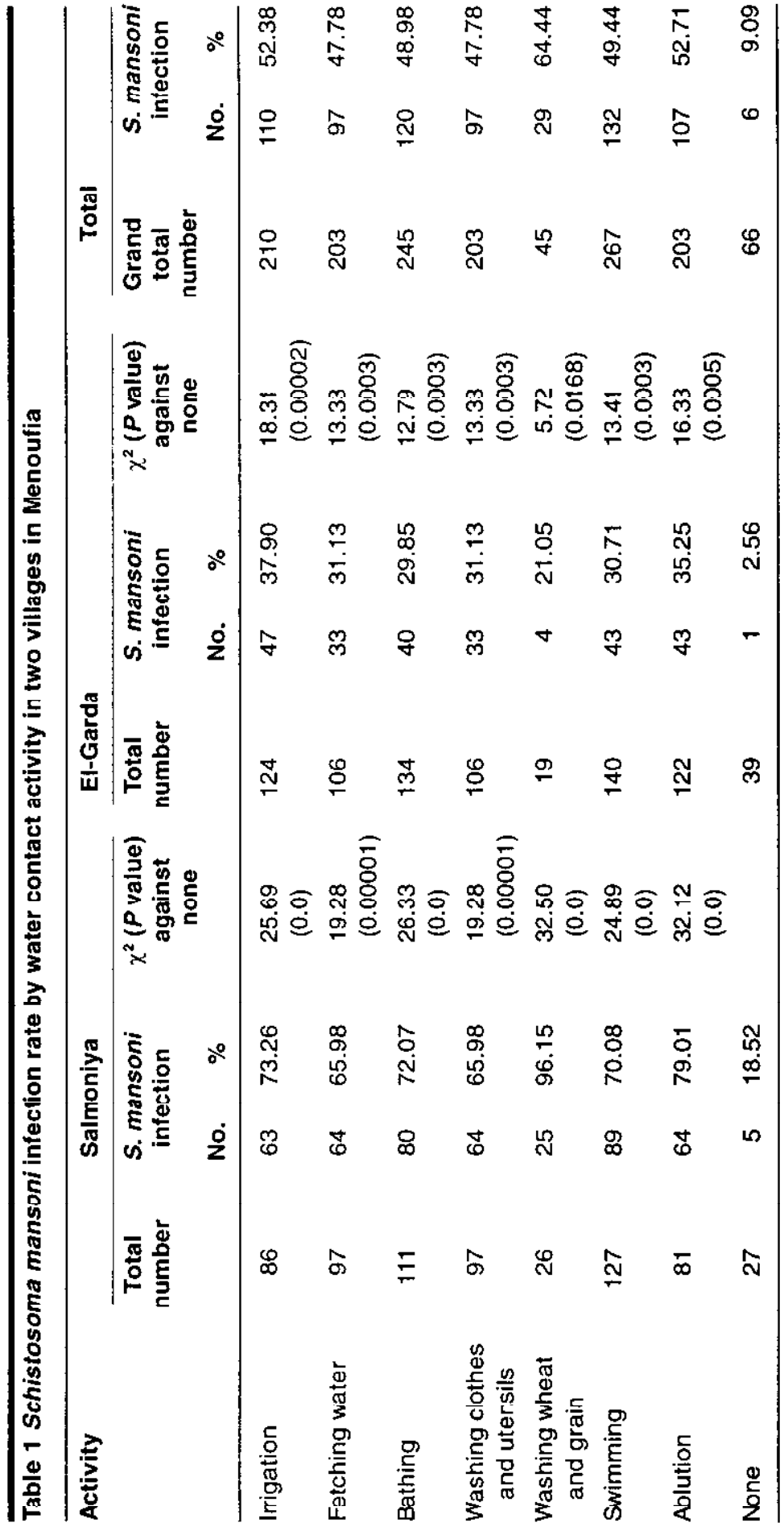

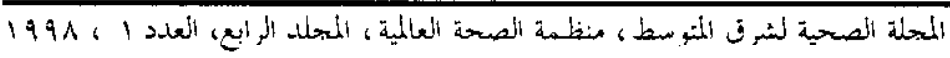


Table 2 Schistosoma mansoni infection rates by habitual water contact canals in two villages in Menoufia

\begin{tabular}{lcccccc}
\hline $\begin{array}{l}\text { Schistosomiasis } \\
\text { infection }\end{array}$ & \multicolumn{2}{c}{ Salamoniya village } & & \multicolumn{2}{c}{ El-Garda village } \\
\cline { 2 - 3 } & $\begin{array}{c}\text { Dia El-Kom } \\
\text { canal }\end{array}$ & $\begin{array}{c}\text { El-Salamoniya } \\
\text { canal }\end{array}$ & & $\begin{array}{c}\text { Kafr Tambidy } \\
\text { canal }\end{array}$ & $\begin{array}{c}\text { El-Garda } \\
\text { canal }\end{array}$ \\
\hline $\begin{array}{l}\text { Number of positive cases } \\
\begin{array}{l}\text { Total number in contact } \\
\text { with water }\end{array}\end{array}$ & 59 & 31 & & 27 & 41 \\
\begin{tabular}{l} 
Infection rate $(\%)$ \\
\hline
\end{tabular} & 61 & 46 & & 55 & 144 \\
\hline
\end{tabular}

"Significant differenco $(T=0.01)$

$x^{2}=7.52, P=0.006$

necessitating the immersion of the lower third to half of the body in the water course or irrigated field for several hours. More over, these activities involve frequent instances of having to go in and out of the water without drying, thus aiding cercarial penetration. This accounts for the high infection rates related to these exposures. On the other hand, Upathan and Sturroek [6] showed that exposure for over 16 minutes caused cercarial penetration in mice to drop, possibly as a result of protection by the skin reaction brought on by the first penetration. Ablution repeatedly exposes body parts which are highly prone to cercarial penetration $[7,8]$; washing following excretion has been shown to be a high-risk activity for infection in previous studies in the Nile Delta [3].

The degree of chemical and faecal pollution of the watcr courses differed greatly in the two villages and also within each village. This is probably due to the existence of the sewage disposal system in El-Garda village and its absence in Salamoniya [9]. In spite of the high pollution of water courses in Salamoniya, which appeared to have a lethal effect on the Schistosoma snail vectors and would thus affect schistosomiasis infection rates, the irrigation scheme of the village never allowed the canals to dry up. Thus, both Bulinus and Biomphlaria snails were found and were often infected. On the other hand, in ElGarda, in spite of the lower pollution of its water courses, which would have been expected to be associated with higher snail counts, particularly in Kafr Tambidy canal which was less chemically polluted, Bultnus truncatus was the only snail found and in very low counts. This could be attributed to the irrigation regime of El-Garda which involved complete drying up of the canals for several consecutive days every round and thus the death of snails, particularly Biomphlaria.

Upathan [10] showed that mice infection rates and worm burdens increased in direct proportion to cercarial concentrations in contact water, which in nature would be related to the viable snail population size. Moreover, Wilkins et al. [11] added the cercarial densities at different sites as a predicting factor in human infection. This could probably account for the difference in infection rates between the two villages, particularly in relation to ablution, which was the activity highly related to schistosomiasis infection in both areas. 


\section{Conclusions and} recommendations

Certain water contact activities appear to be significantly more related to schistosomiasis infection than others and thus they should be given priority in health education and control measures. Moreover, it is obvious that the irrigation system is an element of schistosomiasis control that should not be overlooked and should be planned with regard to crop cultivation and to minimicing the chances of schistosomiasis infection and reinfection. This emphasizes the importance of intersectoral coordination with the agricultural authorities if primary health care efforts are to be effective in combating reinfection with schistosomiasis.

\section{Acknowledgements}

This research was supported by the Egyptian Ministry of Health/USAID-funded Schistosomiasis Research Project, 2630140.2 (Grant 04-05-38). I would like to thank Samiha El-Katsha and Susan Watts, investigators at the project's host institution, the Social Research Centre at the American University in Cairo, for work on the baseline and water contact investigations and in facilitating this study.

\section{References}

1. Farouk $M$ et al. The epidemiology of Schistosoma heamatobium and Schistosoma mansoni infection in Egypt-49 project areas. Bulletin of the World Health Organization, 1996, 35:293-330.

2. Kloos $\mathrm{H}$ et al. Water contact behaviour and schistosomiasis in an Upper Egyptian village. Social science in medicine, 1983, 17:545-62.

3. Khairy AEM et al. Domestic water supplies and community self-help in Sidi Ghazzı, Nile Delta: strategy for schistosomiasis control. Part IV. The role of peasant canal contact activities in schistosomiasis infection. Bulletin of the High Institute of Public Health, 1987, 17(4):85-95.

4. Khairy AEM, Farag H. Schistosomiasis reinfection and community compliance in a primary health care participatory research project in Menoufia, Egypt. Eastern Mediterranean health journal, 1995, 1(2):215-22.
5. Kloos H, Lemma A. The epidemiology of Schistosoma mansoni in Tensae Berhan, Ethiopia. II. Human water contact patterns. Ethiopian medical journal, 1980 , 18:91-8.

6. Upathan ES, Sturrock RF. Studies on the effects of cercarial concentration and length of exposure on the infection of mice by Schistosoma mansoni. Parasitology, 1973, 67:219-28.

7. Jordan P, Webbe G. Schistosomiasis epidemiology and control. London, William Heinemann Medical Books Limited, 1982.

8. Khairy AEM et al. Domestic water supplies and community self-help in Sidi Ghazzi, Nile Delta: a strategy for schisto. somiasis control. Part V. The role of timed canal water contact in human schistosomiasis infection. Bulletin of the High institule of Public Health, 1980, 18(1):129-45.

9. El-Katsha $S$ et al. The role of water supply and sanitation in transmission of 
schistosomiasis, and sources of faecal contamination in surface water in two villages of the Menoufia governorate. Paper presented at Schistosomiasis Research Project International Conference on Schistosomiasis, Cairo, Egypt, 1993.

10. Upathan ES. Studies on the effects of cercarial concentration and length of ex- posure on the infection of mice by St. Lucian Schistosoma mansoni cercariae in a natural running-water habitat. Parasitology, 1974, 68:155-9.

11. Wilkins $H A$ et al. Resistance to reinfection after treatment of urinary schistosomiasis. Transactions of the Royal Society of Tropical Medicine and Hygiene, 1987, 81:29-35.

Schistosomiasis continued to be a public health problem in Egypt, Sudan and Republic of Yemen, particularly in areas where there are water development schemes. Further reductlon of the prevalence of schistosomiasis was achieved by the national programmes in Morocco, Saudi Arabia and Syrian Arab Republic in areas with sustainable control activities.

WHO collaboration with endemic countries covered a variety of areas, Including planning of control, strengthening of diagnostic facllities, provision of drugs for treatment, training of the national staff in methods of surveillance and control of schistosomiasis, distribution of materials for training and health education, and support for research.

WHO continued to collaborate in strengthening laboratory facilities for diagnosis of schistosomiasis in endemic countries. The WHO publication Health Education in the control of schistosomiasis was translated and published in Arabic. WHO supported applied research on the epldemiology of schistosomiasis in Egypt and the Republic of Yemen through the EMRO/TDR/CTD small grants scheme.

Source: I he Work of WHU in the Eastern Mediterranean Kegion. Annual Keport of the Regional Director, I January-31 December 1996. 